\title{
Polysèmes
}

Revue d'études intertextuelles et intermédiales

\section{From Phonograph to Podcast: Reinventing Victorian Fiction Through French Radio Adaptations}

Du phonographe au podcast : réinventer la fiction victorienne à travers les adaptations radiophoniques françaises

\section{Anaïs Martin}

\section{OpenEdition}

\section{Journals}

\section{Electronic version}

URL: http://journals.openedition.org/polysemes/6731

DOI: $10.4000 /$ polysemes. 6731

ISSN: 2496-4212

Publisher

SAIT

\section{Electronic reference}

Anaïs Martin, «From Phonograph to Podcast: Reinventing Victorian Fiction Through French Radio Adaptations », Polysèmes [Online], 23 | 2020, Online since, connection on 02 July 2020. URL : http:// journals.openedition.org/polysemes/6731; DOI : https://doi.org/10.4000/polysemes.6731

This text was automatically generated on 2 July 2020 .

Polysèmes 


\title{
From Phonograph to Podcast: Reinventing Victorian Fiction Through French Radio Adaptations
}

\author{
Du phonographe au podcast : réinventer la fiction victorienne à travers les \\ adaptations radiophoniques françaises
}

Anaïs Martin

1 In the introduction of his 1938 CBS radio adaptation of Bram Stoker's Dracula, Orson Welles presents the novel to his listeners of The Mercury Theater on the Air as "the best story of its kind ever written. You will find it in every representative library of classic English literature" (Welles, "Dracula", 01:55). A couple of months after the launch of his radio show, Orson Welles adapted Jane Eyre, and the young director presented the episode as follows: "Ladies and gentlemen, tonight we bring you a tale of dark secrets, and of a dark and secret love-an English classic, a standard work in our Mercury repertory" (Welles, "Jane Eyre", 00:35). The choices of adaptation seem to have been prompted by the reputation of these "classic" Victorian novels, to which Linda Hutcheon alludes as the "adapted works' cultural cachet" (Hutcheon 91). Both Jane Eyre and Dracula are attractive because their fame precedes them, and they may attract listeners who are fond of nineteenth-century literature, English settings, and gothic atmospheres.

2 Orson Welles's Dracula was the main source of inspiration for the 2015 radio adaptation by France Culture as a concert-fiction. The innovative aspect of this new form of radio creation resides in the collaboration between different sectors of the French radio, on the public recordings of the adaptations, and on the harmony between story and music. 1 The concert-fiction was founded by a reunion of the Department of Fictions of France Culture and the French National Orchestra. ${ }^{2}$ Stéphane Michaka, author and dramatist, Cédric Aussir, radio director, and Didier Benetti, musician and composer, worked together to adapt Stoker's novel as a concert-fiction. Dracula was recorded live in April 2015, with 70 musicians from the Orchestre National de France, 8 actors, 2 foley artists, and 10 sound engineers, in front of an audience of 850 people. It was broadcast 
in April 2015, on a Saturday night, as part of the show "Samedi Noir" (or "Black Saturday"), which targets a general audience and aims at moving, entertaining, and intriguing the listeners. ${ }^{3}$ The show airs each weekend from 9 to $10 \mathrm{pm}-\mathrm{a}$ schedule which seems appropriate for themes such as crime, investigation, and mystery. The one-hour format is however quite restrictive, and many changes were applied to adapt the novel for the radio.

3 France Culture also adapted Jane Eyre into a serial of 10 25-minute episodes in 2015, directed by Juliette Heymann and adapted by Pauline Thimonnier, with the actor JulieMarie Parmentier performing as Jane Eyre. One episode aired every day of the week between 8:30 and 8:55 pm, from December 21, 2015, to January 1, 2016. Jane Eyre was produced for the show Feuilleton, which is advertized on the France Culture website as "30 minutes of radiophonic creation, of great adaptations of classical and contemporary works to mingle all the professions and skills of the radio world". ${ }^{4}$ The total of four hours and eight minutes was a rather comfortable format which allowed for a detailed rendition of Brontë's masterpiece. The form of an adaptation is therefore determined by the slot it is granted in the station schedule. Stories and themes differ according to the time of airing, and the audience's expectations may vary depending on the nature of the show they are listening to.

4 France Culture is a public and state-funded radio broadcaster, asserting at the core of its identity a commitment to the development of artistic creation. The radio channel promotes culture and fiction, either through the development of original programs and series, or through the production of innovative adaptations. According to Hervé Glevarec, France Culture has a function of cultural proselytism, as it should make the listeners want to read more. It also plays a role of entertainment and a part in the endurance of cultural patrimony. ${ }^{5}$ The specificity of France Culture relies on the freedom of its contributors. The French radio claims to encourage innovation and creativity, and to strive to reinvent the radio experience and to satisfy the variety of its listeners through the exploration of new formats deriving from the digital revolution. ${ }^{6}$ The two formats of the feuilleton and the concert-fiction meet these criteria, and the sonorous renditions of novels require a close collaboration between different radio skills. The directors rely on the script written by the adapters to bring the characters to life and to re-create the space and time of the action, while the post-production work of editing and mixing is carried out by sound technicians.

5 This essay focuses on how Victorian literature persists in French culture through contemporary radio drama. It relies mainly on the analysis of France Culture's creative adaptations, and on several interviews that were conducted with the adapters and directors of these adaptations. In an intermedial and intercultural approach, the essay first considers the format of the adaptations, seeing how Victorian plots can either help revive the form of serial narratives or contribute to the creation of new forms. Then it explores the appeal of Victorian fiction for a French audience, based on cultural proximity. It finally considers how the intimacy of the radiophonic medium heightens the atmospheres of the novels, offering the audience an immersive listening experience in past and foreign literature. 


\section{Victorian formats}

6 Jane Eyre and Dracula were adapted into two different formats, which required a different process of dramatization for the radio. The popular nineteenth-century literary form of the serial was used for the production of Jane Eyre while Dracula led to an innovative form of creation, but one common point between both radio dramas was the adapters' simplification of the original text. In the adaptation of Jane Eyre, the action focuses on the evolution of the heroine's character; several non-essential details of the plot are omitted, and some secondary characters disappear. For instance, when Jane goes back to Gateshead before Mrs Reed's death, her stay at her aunt's house lasts over a month and is developed over two chapters in the novel, but only four minutes of the adaptation are dedicated to this passage. The plot is centered on Jane's conversation with her aunt to reach the climax of Mrs Reed's confession of her role in Jane's misfortunes. Bessie's role is also minimized in the adaptation, even though Pauline Thimonnier lamented having to neglect the nursemaid's character and influence on Jane in order to save time (Thimonnier, Skype interview, 19 July 2017). On the other hand, in the adaptation of Dracula, the simplification results in an acceleration. The one-hour format requires the suppression of many details, the condensation of characters, and the simplification of the narrative. As in Orson Welles's 1938 adaptation, Lucy's suitors are less numerous, since the character of Quincy Morris is removed, and both Lord Arthur Godalming and Doctor John Seward become a single character-Docteur Arthur Seward. All the major events of the plot are evoked in Stéphane Michaka's adaptation, but they are not as developed as in the novel. For instance, Jonathan's observations of Dracula's strange behavior in Transylvania are not as numerous as in the novel, as the contemporary French audience is likely to be familiar with all the tropes from the vampire lore. Moreover, Lucy and Mina's stay in Whitby is elided to focus on the result of Dracula's attack on the young woman ("Dracula", Fictions/Samedi noir, France Culture, 19 April 2015, podcast, 26:18). The change of medium and the new formats require simplifications of the original plots so as to emphasize specific characteristics.

7 In spite of the necessary reduction of the source text, Linda Hutcheon and Julie Sanders have shown that Victorian fiction is frequently adapted and that there is a "return again and again to the scene of the mid-nineteenth century for characters, plotlines, generic conventions, and narrative idiom and style" (Sanders 121). In addition, nineteenth-century literature is characterized by its readiness to adapt, because Victorian plots are mainly linear and realist, which makes them easier to follow:

Are some kinds of stories and their worlds more easily adaptable than others? [...] Linear realist novels, it would appear, are more easily adapted for the screen than experimental ones, or so we might assume from the evidence: the works of Charles Dickens, Ian Flemming, and Agatha Christie are more often adapted than those of Samuel Beckett, James Joyce, or Robert Coover. [...] Their strongly pictorial descriptions and potential for scenes of spectacle also make them readily adaptable. (Hutcheon 15)

8 The notion of linearity is important for the adaptation of a novel to the radiophonic medium. Alan Beck, from the university of Kent, underlines that since radio drama solely relies on sound, the plots tend to be linear to maintain some verisimilitude: "Dialogue and the radio drama diegesis impose a linear and 'real' time, which may have little or no elasticity" (Beck n.p.). For example, in Jane Eyre, the plot of the novel 
resembles the form of a Bildungsroman and enables the readers to accompany the heroine through the different stages of her life. The novel was published in three volumes, each one ending on a symbolic event in Jane's life, such as her rescuing Mr Rochester from the fire in his bedroom, or the aborted wedding at Thornfield. The novel was, however, adapted as a "Feuilleton" by France Culture since the linear plot is easy to follow over several episodes and since the serial format seems particularly fitting to modern media: "Many novels were published in instalments, encouraging readerly addiction to plotlines and characters, and honing the authorial skills of creating suspense by means of the 'cliffhanger' ending that still influences contemporary soap opera on radio and television" (Sanders 121). The many unexpected events of the plot in Jane Eyre and the underlying mysteries are suitable for an adaptation of the novel as a serial since they create suspense and push the listeners to play the following episode. For instance, the fifth episode of the adaptation ends on an intriguing event, as Rochester is distressed to hear that "Mason" has come from "Les Antilles..." (The West Indies) ("Jane Eyre, episode 5", Fictions/Le Feuilleton, France Culture, 25 December 2015, podcast, 22:55). His shock is melodramatically emphasized by the fast and sharp violin music, and the lack of explanation makes the listeners long to hear the next episode.

9 In Dracula, the plot is more complex, and its reconstitution depends on the characters, as well as the readers, who have to pay careful attention to all the hints, allusions, and clues scattered by Stoker throughout the narrative. As the plot is less linear, it was more fitting for a new form of radio creation such as the concert-fiction. Stéphane Michaka claims that this new format granted him a large amount of freedom, since the narrative of the radio drama became less realistic with the use of many ellipses. The radio experience is quite magical, in his opinion, because the music allows for very fast and evocative changes in the narrative (Michaka, personal interview, 1 March 2019). ${ }^{7}$ The orchestra often becomes the narrator as it executes dynamic transitions between scenes and settings. For example, the passage between scene 14, set in Dr Seward's living room, and scene 15, set in the Piccadilly Crypt (Michaka, Dracula de Bram Stoker, Fiction radiophonique, 32-33) is depicted by the orchestra ("Dracula", Fictions/Samedi noir, France Culture, 19 April 2015, podcast, 51'07). This musical interlude is characterized by an acceleration of the tempo, conveying the suspense of the action, while the sound of the percussion, similar to the rattling of the train, alludes to the idea of movement and travel. It is this use of music and the live performance of the actors and foley artists in the adaptation that contribute to the originality of the format created by France Culture.

10 The dramatization of novels for the radiophonic medium is also determined by the shortened attention span of the listeners who, without any visual element, tend to be more easily distracted than viewers watching a movie. The adaptations not only reduce the source text, but they also find dynamic ways of keeping the listeners attentive. In Jane Eyre, Pauline Thimonnier created an alternation between inside and outside scenes, so as to keep up the intensity of the adaptation. Her goal was to give as much rhythm and energy to the script as possible in order to create a smooth and captivating listening experience (Thimonnier). Another way to do this is to alternate collective scenes with more intimate settings. For instance, the second episode of the adaptation is focused on Jane's experience in Lowood. The monotony of the days spent in the institution is rendered more lively thanks to an alternation between scenes set in the 
classroom-defined by the sounds of chalk on slates, the girls' whispers, and the voices of the teachers in the background-and scenes set outside, in the courtyard, with the rustle of the vegetation and the schoolgirls' conversations and laughter. Furthermore, Pauline Thimonnier also underlines the notion of equilibrium and the importance of changing points of view in the adaptation (Thimonnier). At the beginning of the eighth episode, Jane's loss of consciousness and her wandering in the Yorkshire land are thus accounted for by the conversation between the Rivers siblings, which is perceived by a sleepy Jane and not related by the narrator. In fact, the occasional withdrawal and discretion of the voice-over narrator favors a variation in points of view and leaves more room for the direct perception of the action by the listeners. Moreover, in Dracula, the omnipresence of the orchestra in the background accompanies the narrative, and the musical intermissions confer energy to the adaptation. Such interludes can revive the listeners' attention or also suggest the characters' feelings. A specific example is the recurrence of the Bohemian song in scenes 1, 4, 10 and 16, which evokes Mina's melancholy and doubts, and which conjures up the mysteries. Alternations in the narrative and musical intermissions can therefore help confer intensity to the adaptation and revitalize these works. With Jane Eyre and Dracula in particular, France Culture therefore participates in the perseverance of Victorian fiction in France, thanks to the transmediation of the serial narrative, but also to the creation of new formats that give prominence to Victorian classics.

\section{Cultural proximity}

Despite the nineteenth-century setting of the works, the themes developed in both novels are still quite evocative for a contemporary audience, which explains why Victorian culture can resonate for French listeners, overcoming cultural and linguistic boundaries. Indeed, Sanders underlines that "the Victorian era throws into relief some of our more contemporary concerns with class and social hierarchy and with questions of empire and colonialism" (Sanders 128). In other words, Victorian themes echo contemporary concerns, which can account for the popularity of both novels and their adaptations. In the French imagination, Jane Eyre is linked to the collective image of the Brontë sisters and their romantic or tragic writings. ${ }^{8}$ When the department of Fictions of France Culture wanted to adapt one of the Brontë sisters' works, they gave the choice of which novel to the adapter. Pauline Thimonnier was free to decide between Jane Eyre and Wuthering Heights, and she chose Charlotte Brontë's novel based on her own sensibility and personal preference (Thimonnier, Skype interview, 19 July 2017). In addition, Jane Eyre displays the resolution of an impossible love and contains several feminist echoes that may be attractive to many readers and listeners. The social and feminist concerns of the novel have been frequently studied: "a tradition of feminist criticism has constructed its romance with Jane Eyre by reading it as a model of resistance, not only to 'the Victorian conception of woman's place' but to 'women's fate within the symbolic order"' (Kaplan 6). The story of the emancipation of a plain woman from the constraints of the Victorian patriarchal society therefore reflects many contemporary issues, such as gender equality, economic justice, or social mobility. Dracula develops themes that seem to have remained attractive to various audiences as well: the story of the fight against evil is universal, the gothic elements have become more and more popular, and the vampire lore echoes themes of contagion, overcoming death, unbridled sexuality, etc. Vampires have been modernized through numerous 
adaptations, and their representation can have a cathartic effect: "Vampires enable us to indulge our deepest fears and desires without directly challenging the moral values against which they are balanced. No creature of the night seems to excite the imagination in quite the same way" (Rydman n.p.). Such themes still resonate with modern radio listeners, even if contemporary visual representations of vampires have tended to smooth over the image of the monster, refocusing plots on the complex personalities of anti-heroes and on their inner fights. In the concert-fiction as in Stoker's novel, however, the vampire comes from foreign lands and the outside threat he represents has to be eradicated. For instance, the chase against Dracula in London is the source of intense suspense, which is emphasized by the rhythm of the orchestra music in the adaptation, and which echoes many battles against evil.

Moreover, Stéphane Michaka maintains that Victorian fiction is appealing because of the sense of space it creates and by the variety of places readers explore through literature. He adds that both Charlotte Brontë and Bram Stoker invented worlds that bear a certain degree of violence. The inhospitability of the environment is therefore present in the adaptations and bears a contemporary relevance, echoing issues such as global warming or migration, that heighten the proximity between Victorian culture and French listeners. According to Michaka, the Victorian novel is more appealing than the French nineteenth-century novel, as it is developed on a larger scale and helps the reader imagine foreign spaces and lands (Michaka, personal interview, 1 March 2019). ${ }^{9}$ $\mathrm{He}$ also underlines the fact that Victorian classics have become part of the French literary tradition (Michaka, personal interview, 1 March 2019). ${ }^{10}$ This form of appropriation of Victorian culture by the French relies on the proximity of both nineteenth-century literary traditions. The French audience can find, in the source texts and in their adaptations, both common referents and exotic elements. Jean Derive thus notes that literature can overcome cultural, chronological and language boundaries thanks to common references, to the updating of the original text, and to a certain degree of connivance. ${ }^{11}$ The concert-fiction, for instance, adapted Dracula to resonate with more contemporary concerns. The updated version of the novel focuses on Mina, her ambiguous character, and her deteriorating relationship with Jonathan. This evocation of a loveless marriage is another modern aspect that helps update the story and make it maybe more relevant to the contemporary audience (Michaka, personal interview, 1 March 2019). ${ }^{12}$ One culture and one epoch can become comprehensible to another thanks to an intercultural transmediation. The French audience might be attracted to an adaptation of English literature because it is somehow exotic, but made accessible to their understanding.

The appeal of foreignness is already present in the source texts through some exotic references. In Dracula, Van Helsing's manner of speaking reveals his foreignness, and Morris's accent reminds the readers of his American origins. In Jane Eyre, Rochester's young ward comes from France and addresses her governess as "Mademoiselle". On several occasions, she even speaks French: "Adèle came running to meet us in the hall, exclaiming-'Mesdames, vous êtes servies!' adding, 'J'ai bien faim, moi!”' (Brontë 108). The inclusion of foreign language references was reproduced in the adaptation. France Culture chose a translation that kept the names of the characters and confers a local colour to the radio drama, so as to convey a part of Victorian culture to the French audience. In the opening scene, Jane is thus asked to call her cousin John "Master Reed". Similarly, throughout the adaptation, the heroine is called "Miss Eyre", 
and her master is referred to as "Mister Rochester". The listeners may not have the language skills that would allow them to discover the original Victorian text in full, but thanks to the radio dramatization of the novels they can appreciate the plots and some parts of the English work while taking in their foreign appeal.

\section{Intimacy and point-of-listening}

14 The adaptation of a novel to the radio implies that the written word becomes oral and aural. The sonorous specificities of the new medium require particular operations and changes for this transmediation ${ }^{13}$ because the radiophonic medium allows for more proximity between the listener and the content of the drama. In fact, Alan Beck argues that the radiophonic experience is fundamentally intimate. According to him, the "listening zone" is akin to a personal listening space, in which the auditory imagination of each listener is kindled: "Part of this personal zone must include where the incoming sonic data is received, personal geography. This means personal spaces, and often the kitchen with its monaural radio, for example, on stereo in a car, or on Walkman headphones" (Beckn.p.). The radio experience will therefore be maximized with optimum listening conditions. The use of headphones then becomes a way to condense the personal geography in order to heighten the immersion of the listener in the radio adaptation. Michael Bull underlines that headphones magnify the listening experience, privatizing the space around the listeners and rejecting outside noises: "Instrumental in creating this immersive state is the use of headphones, which transforms the users' relationship to the environment and creates sonic privacy. [...] Headphones reempower the ear against the contingency of sound in the world, bolstering the individualizing practices of sound reception" (Bull 529). In other words, the proximity of the sound source creates more intimacy between the listeners and the content of the radio drama. A radio rendering of Dracula or Jane Eyre therefore provides the listeners with a personal, intimate and sonorous experience of the original texts.

In written literature, the readers depend on the characters' points of view to perceive the action; in radio drama, listeners depend on the "point-of-listening". Consequently, Alan Beck emphasizes the role of the directors in involving the listeners in the radio rendition of the novel: "The radio's point-of-listening has to be given a precise spatial position [...] The director has to turn the potential confusion of 'hearing' (the perception of many bits of aural information) into active radio 'listening' (retaining and interpreting, and busy use of short-term memory storage which becomes especially engaged in dialogue and narrative)" (Beck n.p.). The position and the movement of the microphones help shape the space in radio drama, and the listeners participate in a sonic experience that requires their active imagination as a result of their proximity to the point-of-listening. The two following examples from Jane Eyre help understand these concepts of sound space, perspective, and point-of-listening. In the eighth episode, Jane is seemingly asleep in Moor House. The sound of her hard breathing helps focus the point-of-listening on the heroine as the listeners perceive the scene through Jane's hearing. The conversation between Diana, Mary and St. John Rivers fills some narrative gaps, and the varying distance of the siblings from the microphone helps the listeners picture the scene and follow the characters' movement across the sound space ("Jane Eyre", episode 8," Fictions/Le Feuilleton, France Culture, 30 December 2015, podcast, 01:00). Similarly, at the beginning of the fourth episode, 
Mrs. Fairfax gives Jane a tour of Thornfield Hall. The point-of-listening is centered on Jane, and her movements are indicated by the sound of her steps on the wooden floor. However, Mrs. Fairfax's voice moves away from the microphone, and the variation of its volume recreates Jane's perception of the housekeeper's movements. When the distant laugh of Bertha Mason is heard, it is perceived through Jane's ears, and the heroine's frightened voice guides the listeners' attention from the remote strange laugh back to the close point-of-listening ("Jane Eyre, episode 4", Fictions/Le Feuilleton, France Culture, 24 December 24, 2015, podcast, 01:07).

Essentially, the immersion of the audience in Jane Eyre relies on the proximity between the listeners and the heroine. The point-of-listening as well as the orality of the firstperson narration create an intimate relationship between Jane and the audience. JulieMarie Parmentier's performance often requires her to act in the "style of intimate radio playing", which Alan Beck defines as the "powerful way for the playwright to let the listener into the internal dialogue of the character's 'me' within the outer 'I"'. This process of "interiorizing" can thus "establish a complicity with the listener, a process as familiar as our own inner ruminations" (Beck n.p.). The point-of-listening and the interiorizing process strengthen the intimacy between the listeners and the heroine, and reinforce their identification to Jane's character. Such moments of introspection are recurrent in the adaptation as they transpose the specificity and complexity of Charlotte Brontë's narrative to the radio medium. The listeners are thus immersed in Jane's story and confidences, with no exterior hindrance, and their identification to the heroine relies on them perceiving the events through Jane's point-of-listening.

\section{Atmospheres and immersion}

Both radio adaptations create a sense of immersion, through the point-of-listening, but also in respect to sound effects that indicate the characters' movements and help the listeners follow the action. Through sound effects, the soundscapes imagined by Charlotte Brontë and Bram Stoker become real and sonorous. In France Culture's Jane Eyre and Dracula, we hear chronologically appropriate soundscapes; there are no contemporary background noises. The movements of the characters are for instance indicated by the rustle of their clothes, and the sounds of the horse-drawn carriages evoke the Victorian past. A similar process was used in the production of Les Misérables by France Culture in 2012. The director François Christophe and the sound designer of the adaptation, Patrick Martinache, recounted in an interview that the sounds used to recreate the eighteenth-century French landscape were recorded in bustling villages of the contemporary, though remote, countrysides in Tibet, China, or Chile (Christophe). These sound constructions summon up soundscapes of previous centuries and confer a certain authenticity to the adaptation, so as to immerse the listeners into past atmospheres.

These atmospheres are called "ambiances" by France Culture directors and creators. Defined by Alan Beck as "sound pictures", they are created by the foley artists' conception of the settings within the studios and the use of any prop that may help them fashion precise and believable sound effects: "To create the acoustic of each scene, the technicians build a 'set', as it is called, in the studios, with microphones, screens (having absorbent or reflective sides), and as required, laying down carpet or wooden planks or flagstones, and with other spot equipment such as a door, steps or a 
window, or glasses, cups and the gravel box" (Beck n.p.). For instance in Jane Eyre, Jane's arrival at Thornfield Hall is characterized by a warm atmosphere. The crackling of the chimney fire, the purr of the cat, the clinking of teacups and Mrs Fairfax's amiable voice create an atmosphere of comfort and conviviality, conferring a positive image to the new place ("Jane Eyre", episode 3, Fictions/Le Feuilleton, France Culture, 23 December 2015, podcast, 15:34). In Dracula, because the adaptation was recorded live, the foley artists, Sophie Bissantz and Élodie Fiat, were on the same stage as the actors and the orchestra. The sound effects were fashioned on the spot to accompany the live performance. The reading of Jonathan's journal, for example, was introduced by the rustling of paper ("Dracula", Fictions/Samedi noir, France Culture, 19 April 2015, podcast, 03'55) and the young man's arrival at Dracula's castle was sonified by the grinding of the door and the harsh bolting of the lock, emphasizing the impression of imprisonment ("Dracula", Fictions/Samedi noir, France Culture, 19 April 2015, podcast, 06'30).

19 Although, as discussed earlier, certain reductions of the original text are a necessary step to radio adaptation, sound technology offers radiophonic solutions to avoid the over-simplification of the adapted text. For example, instead of long descriptions, the sonorous rendering of a landscape can bypass the narrator's intervention, thus favoring the listeners' own direct perception of the soundscape. The howling of wolves or dogs, for instance, is the most emblematic sound of Transylvania in the novel Dracula, as it always foreshadows the arrival of the Count. In the concert-fiction, the howling is recreated thanks to digital sound effects and stimulates the listeners' imagination, reminding them of the fantastic world and evoking the gothic genre without the intervention and description of such sound by a narrator. Sound technicians add a touch of creativity to the adaptation as realistic effects are fathomed through technological tools. They are also in charge of editing and mixing all the recorded takes, as well as treating the sound and applying various effects to them to keep rendering the adaptation as sonic and believable as possible. According to Hervé Glevarec, the editing task is a creative one..$^{14}$ It presents the producers with another chance to confer energy to the drama, maintaining the attention of the listeners and the rhythm of the adaptation..$^{15}$ In the concert-fiction, Dracula's voice is often treated with a reverberating effect to make it seem distant, unreachable, as if to emphasize the fantastic power of the Count. Consequently, sound design participates in the recreation of the Victorian soundscapes of the novels.

In the case of Dracula, the immersion is further intensified by the fact that it was an actual live performance, and the audience could either attend the recording or listen to its broadcast on the channel or later as podcast. The concert-fiction was intended to be a free adaptation of Stoker's work, and because of the format and the technical sound innovations, it did become a rewriting of the novel (Michaka, Skype interview, 4 October 2017). Moreover, this new genre of radio drama benefits from the latest digital sound techniques and radio tools, one of which is the Wave Field Synthesis. The WFS system consists of a large number of loudspeakers (between 30 and 50), which are placed all around an auditorium. This technical installation helps re-create a threedimensional sound space and offers an immersive listening experience. Even though the musicians and the actors are on stage, the sound surrounds the audience, and the spectator/listener perceives the action in a $360^{\circ}$ way. The soundscapes are brought to life by the musical composition; the orchestra sometimes replaces the narrator and suggests actions or expresses feelings better than words would. The objective was to 
achieve some form of synesthesia. Alan Beck thus argues: "So in radio drama, we should base ourselves on its single sensory criterion, hearing, but only broadly so, and allowing for the fusion of senses or synaesthesia in the imaginations of many listeners" (Beckn.p.). The variety of techniques and the full exploitation of the medium specificities as well as the exploration of new forms of radio creation therefore encourage the listeners to reach a synesthetic experience, conjuring up images in their mind's eye with their hearing perceptions. Consequently, the stimulation of the listeners' auditory imagination is an innovative way to make a French audience (re)discover Victorian classic novels.

21 Victorian fiction is therefore well suited for adaptation, but it also fosters new forms of radio creation. Modern and digital sound techniques are a source of radio innovation in the re-invention of Victorian novels. Nineteenth-century formats are reused as they fit the radiophonic medium well, but the medium's technical specificities also allow the adapters to reinterpret Victorian classics in a new and modern light. With the adaptations of Jane Eyre and Dracula, a wider audience is reached across time and in spite of cultural differences. The adaptations of Victorian classics offer a form of enchantment since they can answer the listeners' nostalgia for the Victorian era, thanks to the sonification of past stories and settings.

This taste for a foreign, but well-known, literary culture could best be explained by the French word dépaysement, in its positive connotation. Victorian England is familiar to the French audience, but also somewhat exotic. Listening to the adaptations is a way of momentarily escaping contemporary reality in a foreign environment without being completely lost. The feeling of nostalgic dépaysement is reinforced by the listeners' immersion in Victorian atmospheres through modern recording techniques, enhancing the sonic realness conferred to the adaptations, or through modern listening tools that allow for a more intimate listening experience of the novels. French radio adaptations convey a sense of formal, thematic, and cultural familiarity to its listeners. Thanks to the conservation of these radio adaptations as podcasts, which are easily available for longer periods of time, Victorian fiction persists in contemporary French culture, while immersing the listeners in Brontë's and Stoker's fictional worlds in an innovative way.

\section{BIBLIOGRAPHY}

Beck, Alan. "Point-of-listening in radio plays". Sound Journal (February 1998), https:// www.kent.ac.uk/arts/sound-journal/beck981.html, last accessed 30 January 2017. Brontë, Charlotte. Jane Eyre (1847). Oxford: Oxford UP, 2008.

Bull, Michael. "IPod Culture: The Toxic Pleasures of Audiotopia". The Oxford Handbook of Sound Studies. Trevor Pinch and Karin Bijsterveld (eds). New York: Oxford UP, 2012. 526-543.

Christophe, François. "Paysages sonores”. Interview by Emmanuel Laurentin. La Fabrique de l'histoire, France Culture, 18 March 2013. Audio, 41:10, https://www.franceculture.fr/emissions/ la-fabrique-de-lhistoire/paysage-sonore-14, last accessed 27 December 2019. 
Dann, Lance. "Only half the story: Radio drama, online audio and transmedia storytelling”. The Radio Journal-International Studies in Broadcast \& Audio Media 12.1-2 (2014): 141-154.

Derive, Jean. "La question de l'identité culturelle en littérature", https://halshs.archivesouvertes.fr/halshs-00344040, last accessed 28 December 2019.

“Dracula". Fictions/Samedi noir, France Culture, 19 April 2015. Podcast. France Culture. "Fictions/ Le Feuilleton", https://www.franceculture.fr/emissions/fictions-le-feuilleton, last accessed 27 December 2019.

France Culture. "Fictions/Samedi Noir", https://www.franceculture.fr/emissions/fictionssamedi-noir, last accessed 27 December 2019.

France Culture. "Rentrée 2018 : découvrez la grille de France Culture", https:// www.franceculture.fr/medias/rentree-2018-decouvrez-la-grille-de-france-culture, last accessed 27 December 2019.

Garrigou-Lagrange, Matthieu. “Les sœurs Brontë (1/4)-Le mythe Brontë”. La Compagnie des Auteurs, France Culture, first aired 6 March 2017. Audio, https://www.franceculture.fr/ emissions/la-compagnie-des-auteurs/bronte1, last accessed 27 December 2019.

Glevarec, Hervé. France Culture à l'œuvre: dynamique des professions et mise en forme radiophonique. Paris : CNRS, 2001.

Glevarec, Hervé. La Sériephilie : sociologie d'un attachement culturel et place de la fiction dans la vie des jeunes adultes. Paris : Ellipses, 2012.

Hutcheon, Linda. A Theory of Adaptation. New York: Routledge, 2006.

“Jane Eyre”. Fictions/Le Feuilleton, France Culture, December 21, 2015-January 1, 2016. Podcast.

Kaplan, Carla. "Girl Talk: Jane Eyre and the Romance of Women's Narration”. NOVEL: A Forum on Fiction 30.1 (Autumn 1996): 5-31.

Michaka, Stéphane. "Les yeux écoutent. Dans les coulisses des concerts-fictions". Unpublished article, 2015.

Michaka, Stéphane. Dracula de Bram Stoker, Fiction radiophonique. Radio script entrusted to the author, 2015.

Picker, John M. Victorian Soundscapes. New York: Oxford UP, 2003.

Rydman, Michael. “The Enduring Appeal of Vampires”. Grand Valley Review 5.2 (1989): 44-48, https://scholarworks.gvsu.edu/cgi/viewcontent.cgi?article=1662\&context=gvr, last accessed 27 December 2019.

Sanders, Julie. Adaptation and Appropriation. New York: Routledge, 2006.

Stoker, Bram. Dracula (1897). London: Penguin Books, 2012.

Thimonnier, Pauline. "Les enjeux littéraires et économiques de l'adaptation du roman Jane Eyre pour l'émission Fictions/Le Feuilleton de France Culture". Unpublished lecture, Aix-Marseille University, March 2, 2018.

Welles, Orson. "Dracula”. The Mercury Theater on the Air, CBS, July 11, 1938. Audio, https:// archive.org/details/OrsonWelles-MercuryTheater-1938Recordings/

MercuryTheater38-07-11Dracula.mp3, last accessed 27 December 2019.

Welles, Orson. "Jane Eyre.” The Mercury Theater on the Air, CBS, July 18, 1938. Audio, https:// archive.org/details/MercuryTheaterJaneEyre, last accessed 27 December 2019. 


\section{NOTES}

1. “Si ces enregistrements publics sont une nouveauté, c'est qu'ils visent à une osmose entre la narration par les voix et l'atmosphère créée par la musique” (Michaka 4).

2. "France Culture et la Direction de la Musique de Radio France se sont rapprochées ces dernières années pour imaginer des fictions alliant texte et musique, jouées en public dans les conditions du direct. Parmi ces productions d'un genre nouveau, les 'concert-fictions' associent l'Orchestre National de France à des comédiens et bruiteurs" (Michaka 1).

3. "Un rendez-vous destiné au grand public : ces fictions auront pour mission de nous émouvoir, nous divertir, nous intriguer", "Fictions/Samedi Noir", France Culture, https:// www.franceculture.fr/emissions/fictions-samedi-noir, last accessed 27 December 2019.

4. "30 minutes d'espace de création radiophonique, de grandes adaptations d'œuvres du patrimoine classique et contemporain pour mêler tous les métiers et les talents de la radio", "Fictions/Le Feuilleton", France Culture, https://www.franceculture.fr/emissions/fictions-lefeuilleton, last accessed 27 December 2019.

5. "France Culture est susceptible d'une telle approche par les fonctions qu'elle remplit. Pour les professionnels, elle assure une fonction de prosélytisme culturel ('donner envie de lire des livres'), de distraction, de patrimonialisation" (Glevarec 27).

6. Sandrine Treiner, director of France Culture, wrote in the September 2018 editorial: “Transmettre notre engagement pour la culture, participer en tant qu'acteur à la vie culturelle, tels sont les buts que nous poursuivons en œuvrant pour élargir encore nos publics et répondre à la révolution numérique. Podcasts natifs en fiction comme en documentaire, nouveaux formats et nouvelles écritures enrichissent l'offre de programmes et d'information de France Culture", Sandrine Treiner, "Rentrée 2018 : découvrez la grille de France Culture".

7. “La liberté est dans le fait que la narration n'est pas du tout réaliste, parce qu'on se permet d'énormes ellipses. C'est la magie de la radio aussi. La musique commande l'espace, et nous fait passer d'un seul coup de Whitby à l'océan, par une seule note de musique. Un changement de lieu qui est amené par une virgule sonore, par l'entrée d'un instrument dans la fiction" (Michaka, personal interview).

8. The first episode of a series on the Brontë sisters for the radio show La Compagnie des auteurs was thus entitled "The Brontë myth" (see Garrigou-Lagrange).

9. "Le roman français au dix-neuvième siècle est très riche, mais souvent c'est Paris ou la province. Alors que la littérature anglaise, parce qu'ils avaient presque trois quarts des terres émergées, c'était les colonies anglaises. L'imaginaire victorien dans les romans était plus voyageur" (Michaka, personal interview).

10. "Il y a un imaginaire géographique qui est très puissant dans le roman victorien, qui l'est peut-être moins dans le roman français, qui est beaucoup plus réaliste, si on prend Balzac ou Flaubert. C'est une littérature qui est très connue en France, qui est très traduite et appréciée. On a des bons récepteurs de littérature victorienne. Ça fait partie, à l'égal des romans français du dix-neuvième, la littérature victorienne fait partie de notre patrimoine ; on se l'est appropriée" (Michaka, personal interview).

11. "[L]a question de l'interculturel en littérature est loin de se limiter à une question interethnique ou interlinguistique (même si ces niveaux gardent une certaine pertinence) car les complicités appelées sont souvent plus fines et d'autres recherches de connivences peuvent venir recouper, voire contrarier celles-là : connivences d'époques, connivences sociales, etc." (Derive 8).

12. "Je pense que [mon adaptation] oriente énormément la lecture sur le personnage de Mina, comme étant quelqu'un de fondamentalement ambigu. C'est une lecture [...] qui est modernisée. C'est ce que j'appelle l'entrée ibsenienne dans le personnage. Elle est plus vénéneuse, plus 
ambiguë dans mon adaptation. On sent qu'elle n'est pas épanouie dans son couple, et c'est assez moderne" (Michaka, personal interview).

13. Linda Hutcheon highlights that medium specificity is particularly at stake with the transmediation of literature to the radio: "Rather, it is when adaptations make the move across modes of engagement and thus across media, especially in the most common shift, that is, from the printed page to performance in stage and radio plays, dance, opera, musical, film, or television, that they find themselves most enmeshed in the intricacies of the medium-specificity debates" (Hutcheon 35).

14. "Bien que pratiqué par toutes les radios, dans le cadre du reportage ou des appels téléphoniques enregistrés par exemple, le montage est ici une étape créatrice, voire artistique, de l'émission" (Glevarec 209).

15. “[Les professionnels de radio] cherchent, comme le dit l'un deux, à 'maintenir l'attention et à maintenir la tension"' (Glevarec 228).

\section{ABSTRACTS}

"He placed me in a comfortable chair, and arranged the phonograph so that I could touch it without getting up, and showed me how to stop it in case I should want to pause. [...] I put the forked metal to my ears and listened" (Dracula, Chapter 17). Such a simple gesture as putting on headphones has become usual nowadays. The representation of this gesture in Dracula however suggests how important sounds were in the Victorian era. The Industrial Revolution led to the enhancement of sound technology, through the invention and the use of the telephone and the phonograph, and such improvements had an impact on Victorian authors and their narratives, though the sound features of their novels tend to be overlooked. This essay focuses on how Victorian literature persists in French culture and how it is reinvented through contemporary radio drama. It explores the main strategies of transmediation needed when adapting a novel to the radio. The essay thus reflects on the popularity of Victorian fiction in France and on its easiness to adapt. It considers how French radio reinvents Victorian literature through new formats and modern sound techniques. The examples analyzed from contemporary radio are the production of Jane Eyre as a serial by France Culture in 2015 and the production of Dracula as a "concert-fiction"-a specific format created by Radio France. These models from contemporary radio demonstrate that Victorian literature fosters new forms of creation.

Cet article s'attache à étudier la façon dont la littérature victorienne persiste dans la culture française et est réinventée, grâce aux adaptations radiophoniques contemporaines, à travers de nouveaux formats et des techniques sonores innovantes. Les exemples analysés sont les adaptations de Jane Eyre, sous forme de feuilleton produit par France Culture en 2015, et le «concert-fiction» de Dracula: un format original imaginé par Radio France en 2014. Ces exemples de fictions radiophoniques contemporaines démontrent que la littérature victorienne stimule de nouvelles formes de création. Cette approche intermédiale considère les intrigues linéaires victoriennes, faciles à simplifier et adapter, comprenant des éléments nécessaires à la stimulation de l'attention des auditeurs et contribuant à la création de nouveaux formats radiophoniques. L'attrait de la fiction victorienne pour des auditeurs français et le processus de transmédiation interculturelle reposent en outre sur la résonance contemporaine de certains thèmes victoriens, sur une proximité culturelle et littéraire, mais aussi sur une certaine nostalgie 
du passé victorien. L'intimité de l'expérience d'écoute liée au médium radiophonique renforce la proximité et l'identification entre les personnages et les auditeurs. L'immersion et le dépaysement des auditeurs dans des ambiances et atmosphères victoriennes sont ainsi intensifiés par les outils sonores modernes.

\section{INDEX}

oeuvrecitee Jane Eyre, Dracula

Mots-clés: adaptation radiophonique, interculturalité, transmédiation, immersion, dépaysement

Keywords: radio adaptation, interculturality, transmediation, immersion

\section{AUTHORS}

\section{ANAÏS MARTIN}

Anaïs Martin is a PhD candidate at Aix-Marseille University. She passed the Agrégation in 2014, and taught as a French instructor at the University of Wisconsin-Madison in 2015. She now holds a position of ATER (teaching assistant) and teaches English literature at Aix-Marseille University. Her dissertation, under the supervision of Professor Nathalie Vanfasse, is about new technologies and new habits of reading. She is particularly interested in the representation of sounds in Victorian fiction, and also in the strategies needed for their radio adaptation. She is part of the research group LERMA (Laboratoire d'Études et de Recherche sur le Monde Anglophone). Some of her recent interventions include: "Sound Modernity in Dracula" and "Transmediating Dracula into Contemporary French Radio Drama" (Conference "Form across literature and the sciences", UC Berkeley, 2018), "Rémanence(s) victorienne(s) : les adaptations radiophoniques contemporaines" (Conference "Rémanence", Aix-Marseille University, 2017), "Une expérience littéraire et acousmatique inédite : les adaptations radiophoniques des paysages sonores victoriens” (Symposium “Voix acousmates”, Rennes 2 University, 2017), “Les enjeux économiques des adaptations littéraires radiophoniques" (Conference "Littérature-économie" Aix-Marseille University, 2015). 